\title{
Chitosan microparticles as injectable scaffolds for tissue engineering
}

\author{
Dunia Mercedes García Cruz ${ }^{1}$, Jorge Luis Escobar Ivirico ${ }^{1}$, Manuela M. Gomes ${ }^{2,3}$, Jose Luis Gómez \\ Ribelles $^{1,4,5}$, Manuel Salmerón Sánchez ${ }^{1,4,5}$, Rui L. Reis ${ }^{2,3}$ and João F. Mano ${ }^{2,3 *}$ \\ ${ }^{1}$ Centre for Biomaterials, Universidad Politécnica de Valencia, 46022 Valencia, Spain \\ ${ }^{2} 3$ Bs Research Group - Biomaterials, Biodegradables and Biomimetics, Department of Polymer Engineering, University of Minho, \\ 4710-057 Braga, Portugal \\ ${ }^{3}$ Institute for Biotechnology and Bioengineering (IBB), PT Government Associated Laboratory, Braga, Portugal \\ ${ }^{4}$ Regenerative Medicine Unit, Centro de Investigación Príncipe Felipe, Autopista del Saler 16, 46013 Valencia, Spain \\ ${ }^{5}$ CIBER en Bioingeniería, Biomateriales y Nanomedicina, Valencia, Spain
}

\begin{abstract}
The use of chitosan microparticles as injectable carriers for cell transplantation represents a promising alternative to avoid the drawbacks of the implantation of other forms of three-dimensional (3D) scaffolds seeded with cells. In this study, a 3D construct is obtained in vitro by combining chitosan microparticles crosslinked with genipin and goat bone marrow stromal cells (GBMCs). Cell viability and the morphology of GBMCs were evaluated after culture for 7 and 14 days. Our results show the feasibility of chitosan microparticles as potential injectable scaffolds for tissue engineering and regenerative medicine. Copyright $\odot 2008$ John Wiley \& Sons, Ltd.
\end{abstract}

Received 13 May 2008; Accepted 22 May 2008

Keywords chitosan microparticles; injectable scaffolds; stem cells; tissue engineering; minimally invasive surgical procedures

Tissue engineering has progressed from the use of biomaterials, as a possible therapy for damaged tissue and organs (Langer and Vacanti 1993). Several studies have focused on seeding cells onto three-dimensional (3D) porous scaffolds in the form of hydrogels (Lee and Mooney, 2001), sponges (Tsang and Bhatia, 2004; Escobar et al., 2007), fibers (Chew et al., 2008), meshes (Tuzlakoglu et al., 2004; Rodriguez et al., 2008) or films (Costa et al., 2007; da Silva, 2007) in order to guide tissue regeneration.

Recently, microspheres have also been assessed as scaffold for tissue engineering and new strategies, such as sintering (Borden et al., 2002) and fusion (Malafaya et al., 2005; Jaklenec et al., 2008) methods, have been investigated to obtain suitable scaffolds that mimic the tissue environment for cells (Silva et al., 2007; Curran et al., 2005). Most of the concepts based on the use of

\footnotetext{
*Correspondence to: João F. Mano, 3Bs Research Group Biomaterials, Biodegradables and Biomimetics, Department of Polymer Engineering, University of Minho, 4710-057 Braga,
} Portugal. E-mail: jmano@dep.uminho.pt such scaffolds require the implantation kind of the hybrid constructs through a surgical procedure.

In this work, our goal is to combine isolated particles and cells previously incubated on their surface as a potential alternative in the context of a minimally invasive strategy, as one expects that the particles might agglomerate after implantation as a consequence of cell proliferation and extracellular matrix production playing the role of the 3D scaffold.

Chitosan has been used in the production of scaffolds for tissue engineering (Tuzlakoglu et al. 2004; Oliveira et al. 2006); simultaneously, chitosan particles have been also proposed to be used for the delivery of therapeutic molecules (Prabaharan and Mano, 2005). We will use this system to prove the above-mentioned concept. Chitosan microparticles were prepared by an emulsion crosslinking technique (Denkbas et al., 1999; Al-Helw et al., 1998). Briefly, 2 wt $\%$ chitosan solution in acetic acid $1 \% \mathrm{v} / \mathrm{v}$ was added to mineral oil, containing a surfactant (Tween 80) to form the w/o emulsion. Genipin, a molecules extracted from the fruits of Gardenia jasminoides Ellis was used as the crosslinking agent 
(Butler et al., 2003) at different concentrations (20 or $40 \mathrm{~mm}$ ). Emulsion was stirred overnight for $17 \mathrm{~h}$ and the crosslinked chitosan microparticles were recovered by centrifugation. The morphological, surface appearance and the size of crosslinked chitosan microparticles were examined by optical microscopy (Figure 1) showing darkbluish coloured spherical particles with very smooth surface. The microsphere diameter was $70 \pm 20 \mu \mathrm{m}$ and $60 \pm 10 \mu \mathrm{m}$ for crosslinked particles with 20 and $40 \mathrm{~mm}$ genipin, respectively. The colour was deepened with the increase of genipin concentration and bluish colour was attributed to double bonds in the genipin crosslinking molecules.

To analyse the biological response, goat bone marrow stromal cells (GBMCs) were seeded on chitosan microparticles and cultured for 7 and 14 days. Cell viability and proliferation, as evaluated by the MTS assay (Figure 2), demonstrate that the studied chitosan provided an adequate environment for cell attachment and growth. Viability was higher for cell cultures with chitosan microparticles crosslinked with genipin solution $20 \mathrm{~mm}$ than $40 \mathrm{~nm}$ (Figure 2). The crosslinking with genipin is produced through amine bonds and therefore a higher number of free amine groups is expected to appear at the surface of the less cross-linked microsphere, which could enhance cell attachment and consequently cell viability.

Cell morphology evaluated by SEM (Figure 3) demonstrated that after 7 days of culture the cells attached and grew favourably on the microparticles, forming interparticulate cellular bridges and small cell-particle aggregates. Note that cells are in the order of magnitude or bigger than microspheres. Cells spread actively extending filopodia that adhere on a number of substrate particles. It can be said that on the one hand cell allow
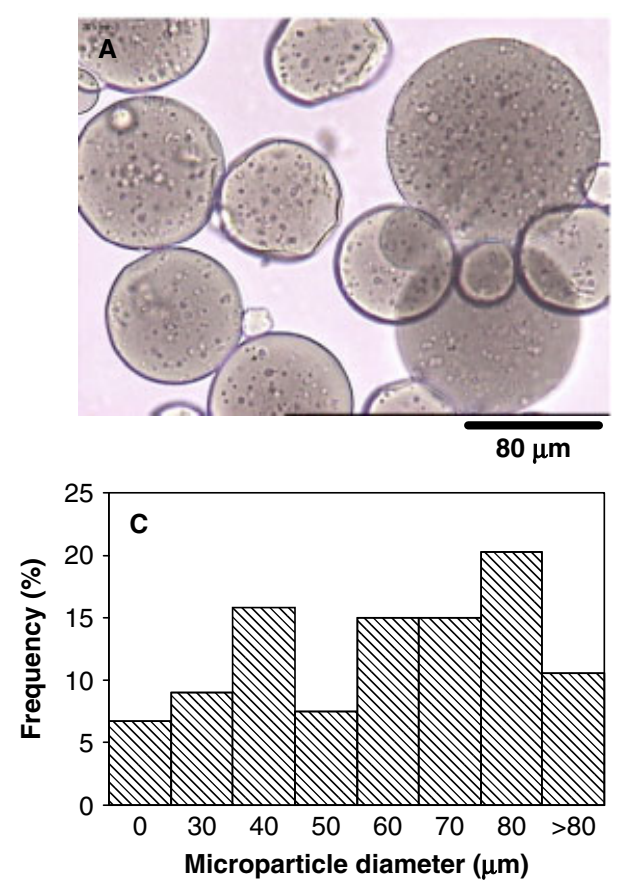

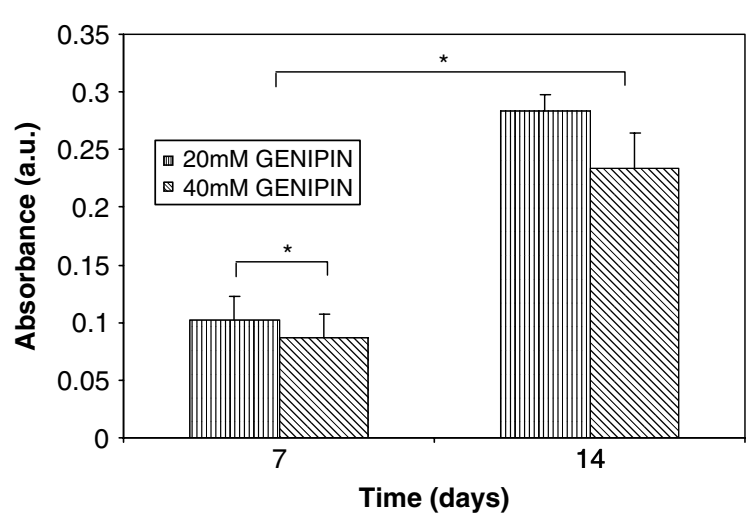

Figure 2. MTS assay performed on chitosan microparticles cultured with GBMCs. Data represented are mean \pm SD. ${ }^{*} p<0.05$

microparticles to join together and on the other hand it is precisely this cell-microparticle spatial arrangement what allows chitosan to play the role of a 3D scaffold that surrounds cells. Besides, unlike conventional scaffolds, this system is highly dynamic in nature and microparticles will be displaced during cell growth, allowing the natural expansion of the tissue. Non-treated chitosan particles were used in this work for the proof of concept. However, new possibilities are open to broaden this concept. For example, combination of different kinds of particles, made of different materials or with more complex size distribution, could be used; moreover, the surface of the particles could be easily modified or a wide range of therapeutical molecules, including soluble factors, could be encapsulated in order to control cell adhesion, differentiation and proliferation.
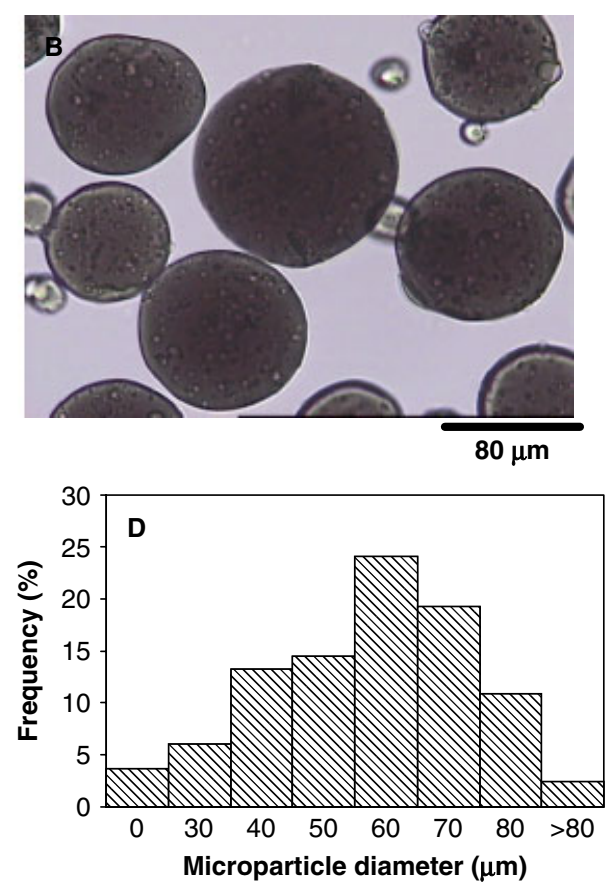

Figure 1. Morphology of chitosan microparticles cross-linked with a solution of $20 \mathrm{~mm}$ (A) and $40 \mathrm{~mm}$ (B) genipin. Their respective microparticle diameter histograms are represented in (C) and (D) 

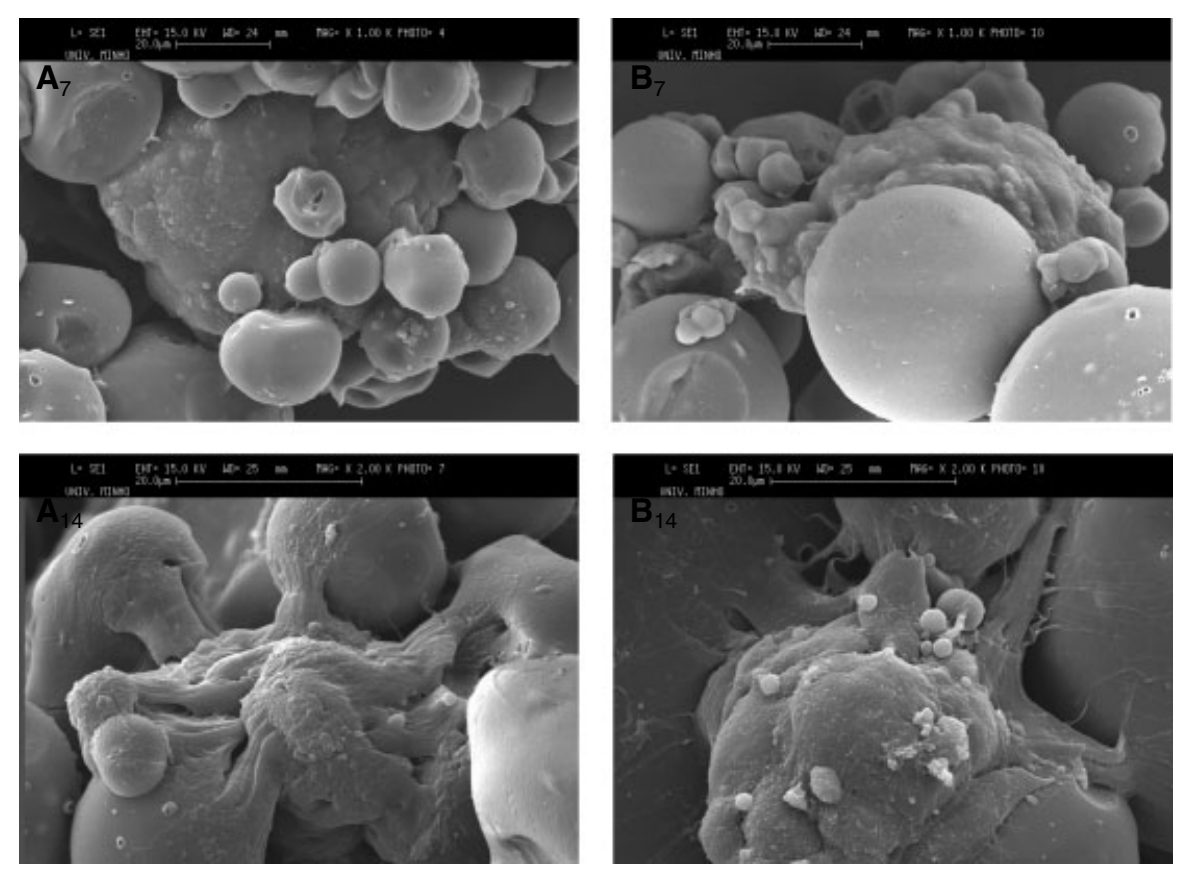

Figure 3. SEM microphotographs of GBMCs on chitosan microparticles. (A, B) Images correspond to crosslinked microparticles with 20 and $40 \mathrm{~mm}$ genipin, respectively; the subindices represent 7 and 14 days of culture

In conclusion, genipin-crosslinked chitosan microspheres support GBMCs adhesion and proliferation without the need of any specific surface treatment. Cells spread on the surface of the microspheres joining them to form a $3 \mathrm{D}$ construct in which microparticles play the role of the scaffold. Crosslinking density affects cell viability slightly but significantly. Such systems could be used in tissue-engineering strategies involving minimally invasive procedures to deliver a combination of cell, growth factors and supporting material.

\section{Acknowledgements}

Support from the Generalitat Valenciana through a shortterm fellowship (No. BEFPI/2007/012) is kindly acknowledged. D.M.G.C. and J.L.G.R. acknowledge the support of the Spanish Ministry of Science through Project No. MAT2007-66759-C0301 (including FEDER financial support). This work was also partially supported by the European Union-funded STREP Project HIPPOCRATES (NMP3-CT-2003-505758), and the European NoE EXPERTISSUES (NMP3-CT-2004-500283).

\section{References}

Al-Helw AA, Al-Angary AA, Mahrous GM, et al. 1998; Preparation and evaluation of sustained release cross-linked chitosan microspheres containing phenobarbitone. J Microencapsul 15: 373-382.

Borden M, Attawia M, et al. 2002; The sintered microsphered matrix for bone tissue engineering: in vitro osteoconductivity studies. $J$ Biomed Mater Res 61: 421-429.

Butler MF, Ng YF, Pudney PDA. 2003; Mechanism and kinetics of the crosslinking reaction between biopolymers containing primary amine groups and genipin. J Polym Sci 41: 3941-3953.

Chew SY, Mi R, Hoke A, et al. 2008; The effect of the alignment of electrospun fibrous scaffolds on Schwann cell maturation. Biomaterials 29: 653-661.
Costa Martínez E, Escobar Ivirico JL, Muñoz Criado I, et al. 2007; Effect of poly(L-lactide) surface topography on the morphology of in vitro cultured human articular chondrocytes. J Mater Sci 18: 1627-1632.

Curran SJ, Chen R, Curran JM, et al. 2005; Expansion of human chondrocytes in an intermittent stirred flow bioreactor, using modified biodegradable microspheres. Tissue Eng 11: 1312-1322.

Denkbas EB, Seyyal M, Piskin E. 1999; 5-Fluorouracil loaded chitosan microspheres for chemoembolization. $J$ Microencapsul 16: $741-749$.

Escobar Ivirico JL, Costa Martínez E, Salmerón Sánchez M, et al. 2007; Structure and properties of methacrylated-endcapped caprolactone networks with modulated water uptake for biomediacal applications. J Biomed Mater Res 83: 266-275.

Jaklenec A, Wan E, Murray ME, et al. 2008; Novel scaffolds fabricated from protein-loaded microspheres for tissue engineering. Biomaterials 29: 185-192.

Langer R, Vacanti JP. 1993; Tissue engineering. Science 260: 920-926.

Lee KY, Mooney DJ. 2001; Hydrogels for tissue engineering. Chem Rev 101: 1869-1879.

Malafaya PB, Pedro AJ, Peterbauer A, et al. 2005; Chitosan particles agglomerated scaffolds for cartilage and osteochondral tissue engineering approaches with adipose tissue derived stem cells. J Mater Sci Mater Med 16: 1077-1085.

Oliveira JM, Rodrigues MT, Silva SS, et al. 2006; Novel hydroxyapatite/chitosan bilayered scaffold for osteochondral tissue-engineering applications: scaffold design and its performance when seeded with goat bone marrow strombal cells. Biomaterials 27: 6123-6137.

Prabaharan M, Mano JF. 2005; Chitosan based particles as controlled drug delivery systems. Drug Delivery 12: 41-57.

Rodríguez Hernández JC, Serrano Aroca A, Gómez Ribelles JL, et al. 2008; Three-dimensional nanocomposite scaffolds with ordered cylindrical orthogonal pores. J Biomed Mater Res 84: 541-549.

Silva GA, Coutinho OP, Ducheyne P, et al. 2007; Materials in particulate form for tissue engineering. 2. Applications in bone. $J$ Tissue Eng and Reg Med 1: 97-109.

da Silva RMP, Mano JF, Reis RL. 2007; Smart thermo-responsive coatings and surfaces: switching cells-materials boundaries. Trends Biotechnol 25: 577-583.

Tsang VL, Bhatia SN. 2004; Three-dimensional tissue fabrication. Adv Drug Del Rev 56: 1635-1647.

Tuzlakoglu K, Alves CM, Mano JF, et al. 2004; Production and characterization of chitosan fibers and 3D fiber mesh scaffolds for tissue engineering applications. Macromol Biosc 4: 811-819. 